GRASAS Y ACEITES 71 (1)

January-March 2020, e339

ISSN-L: 0017-3495

https://doi.org/10.3989/gya.1063182

\title{
Effect of process variables on the yield and quality of jerivá (Syagrus romanzoffiana) kernel oil from aqueous extraction
}

\author{
K.T. Magalhães ${ }^{\mathrm{a}}$, T.S. Tavares ${ }^{\mathrm{a}}$, T.M.C. Gomes ${ }^{\mathrm{b}}$ and C.A. Nunes ${ }^{\mathrm{b}, \mathrm{\varpi}}$ \\ ${ }^{a}$ Department of Chemistry, Federal University of Lavras, University Campus, \\ Post Office Box 3037, 37200-000 Lavras, Minas Gerais, Brazil. \\ ${ }^{\mathrm{b}}$ Department of Food Science, Federal University of Lavras, University Campus, \\ Post Office Box 3037, 37200-000 Lavras, Minas Gerais, Brazil. \\ ${ }^{凶}$ Corresponding author: cleiton.nunes@ufla.br
}

Submitted: 31 October 2018; Accepted: 25 February 2019; Published online: 13 January 2020

\begin{abstract}
SUMMARY: The fruit from jerivá (Syagrus romanzoffiana) has a kernel which is rich in oil, and has a pleasant smell that reminds one of coconut. It is rich in monounsaturated and saturated fatty acids, in addition to bioactive compounds. In this work, the effect of process variables on the yield and quality of jerivá kernel oil from aqueous extraction was evaluated using response surface methodology. The variables $\mathrm{pH}$, time and temperature influenced the yield and the quality of the oil. High $\mathrm{pH}$ and time, along with mild temperature were suitable conditions to extract jerivá kernel oil by aqueous extraction, but excessively high $\mathrm{pH}$, temperature and time negatively impacted the oil's quality. $\mathrm{pH}$ was the only variable that significantly influenced free acidity, with a decrease in free acidity with the increase in $\mathrm{pH}$. On the other hand, the increase in $\mathrm{pH}$, time and temperature increased the peroxide value, which limited some conditions for obtaining jerivá kernel oil by aqueous extraction. The optimal conditions were found to be an extraction at $\mathrm{pH} 12,25^{\circ} \mathrm{C}$ and 60 minutes, which resulted in a yield of $39 \%$, free acidity of $0.2 \%$ and a peroxide value of $5.8 \mathrm{meqO} \mathrm{O}_{2} \cdot \mathrm{kg}^{-1}$. Aqueous extraction yielded more unsaturated oil than that extracted with hexane, in addition to a higher proportion of caproic, oleic and linoleic acids, thus improving its nutritional characteristics and health benefits, despite decreasing its oxidative stability.
\end{abstract}

KEYWORDS: Fatty acid; Lipid; Palm; Response surface methodology

RESUMEN: Efecto de las variables del proceso sobre el rendimiento y la calidad del aceite de almendra de yerivá (Syagrus romanzoffiana) mediante extracción acuosa. La fruta de yerivá (Syagrus romanzoffiana) tiene un grano rico en aceite, que tiene un olor agradable que recuerda al coco, es rico en ácidos grasos monoinsaturados y saturados, además de compuestos bioactivos. En este trabajo, se evaluó el efecto de las variables del proceso sobre el rendimiento y la calidad del aceite de grano de yerivá a partir de la extracción acuosa utilizando la metodología de superficie de respuesta. Las variables $\mathrm{pH}$, tiempo y temperatura influyeron en el rendimiento y la calidad del aceite. $\mathrm{pH}$ alto, elevado tiempo y temperatura suave fueron las condiciones adecuadas para extraer el aceite de grano de yerivá mediante extracción acuosa. Sin embargo, el pH, la temperatura y el tiempo excesivamente altos impactaron negativamente en la calidad del aceite. El pH fue la única variable que influyó significativamente en la acidez libre, con una disminución de la acidez con el aumento del $\mathrm{pH}$. Por otra parte, el aumento del $\mathrm{pH}$, el tiempo y la temperatura aumentaron el valor del peróxido, lo que limitó algunas condiciones para obtener aceite de grano de yerivá por extracción acuosa. Se encontró que la condición óptima fue una extracción a pH 12, $25^{\circ} \mathrm{C}$ y 60 minutos, lo que resultó en un rendimiento del $39 \%$, una acidez libre del $0,2 \%$ y un valor de peróxido de $5,8 \mathrm{meqO}{ }_{2} \cdot \mathrm{kg}^{-1}$. La extracción acuosa produjo más aceite insaturado que el extraído con hexano, además de una mayor proporción de caproico, oleico y linoleico, mejorando sus características nutricionales y beneficios para la salud, a pesar de disminuir su estabilidad oxidativa. 
PALABRAS CLAVE: Ácido graso; Lípidos Palma; Metodología de superficie de respuesta

ORCID ID: Magalhães KT https://orcid.org/0000-0001-7976-7148, Tavares TS https://orcid.org/0000-0002-2275-3113, Gomes TMC https://orcid.org/0000-0002-2956-8674, Nunes CA https://orcid.org/0000-0002-5147-7357

Citation/Cómo citar este artículo: Magalhães KT, Tavares TS, Gomes TMC, Nunes CA. 2020. Effect of process variables on the yield and quality of jerivá (Syagrus romanzoffiana) kernel oil from aqueous extraction. Grasas Aceites 71 (1), e339. https://doi.org/10.3989/gya.1063182

Copyright: C2020 CSIC. This is an open-access article distributed under the terms of the Creative Commons Attribution 4.0 International (CC BY 4.0) License.

\section{INTRODUCTION}

In recent years, the global consumption of vegetable oil has experienced constant growth. At the same time, the increased demand for vegetable oils as an alternative to petroleum has intensified the competition among potential exporters, contributed to the reduction in inventory levels and low availability of vegetable oils, and also sustained high prices (Coimbra and Jorge 2011; Barbosa et al., 2008). Given the increased demand for oil with different characteristics and applications, the search for new oil sources has become necessary.

The Syagrus romanzoffiana palm, known as queen palm, coco palm or jerivá, is found in most tropical and subtropical areas. The jerivá fruit is a yellowish or orange drupe, with a round or oval shape, with a rigid endocarp covering an oily almond. The almond (kernel) oil has a pleasant smell similar to coconut, is rich in saturated and monounsaturated fatty acids, mainly oleic and lauric, in addition to bioactive compounds, such as phenolics, carotenoids, and tocopherols (Pierezana et al., 2015; Coimbra and Jorge, 2012; Coimbra and Jorge, 2011). jerivá kernel oil (JKO) has interesting characteristics for human consumption (Coimbra and Jorge, 2011; Lescano et al., 2018), but also has potential for biofuel production (Moreira et al., 2013; Falasca et al., 2012).

The conventional methods for oil extraction are organic solvent extraction and screw press. However, another method based on aqueous extraction provides the recovery of oils with good quality and yield. This process comprises milling and stirring the feedstock with water at a suitable $\mathrm{pH}$ and temperature, which breaks the vegetable cells and allows the extraction of oil from plant tissues (Khoei and Chekin, 2016; Mat Yusoff et al., 2016). This method has been used efficiently to extract oils from different sources, such as soybeans (Campbell et al., 2011), rice bran (Khoei and Chekin, 2016) and maize germ (Nikiforidis and Kiosseoglo, 2009).

Some process variables can influence the yield and the oil quality in an aqueous extraction, such as feedstock/water ratio, $\mathrm{pH}$, time, temperature and agitation speed, which can vary among different feedstock (Ghorbanzadeh and Rezaei, 2017, Hanmoungjai et al., 2000). Hanmoungjai et al.,
(2000) reported that agitation speed and solid/water ratio did not influence the yield of rice bran oil in an aqueous extraction process, but about $80 \%$ of oil recovery at $\mathrm{pH} 12$ was achieved against less than $40 \%$ at $\mathrm{pH} \mathrm{3}$, besides some improvement at high temperature and time. Rosenthal et al., (1998) also observed a higher yield from the aqueous extraction of soybean oil at $\mathrm{pH}$ above 8 but verified an irrelevant effect of the solid/water ratio.

An aqueous extraction method can be much safer and more environmentally friendly and economical, mainly compared to solvent extraction. Besides, aqueous extraction can produce oils with characteristics which are different from those extracted by other methods, such as a higher content of unsaturated fatty acids (Ghorbanzadeh and Rezaei, 2017) or lower content of free fatty acid and lower colorimparting components (Khoei and Chekin, 2016). Therefore, an aqueous extraction process can yield JKO which is more unsaturated and with better physicochemical quality than that extracted with an organic solvent. These characteristics can have a positive impact on the use of the JKO for consumption when a high content of unsaturated fatty acids, mainly monounsaturated, is nutritionally desirable (Garcés et al., 2017).

This work aimed to evaluate the effect of process variables on the yield and the physicochemical quality of JKO in an aqueous extraction using a five-level tree-variable central composite design and response surface methodology. In addition, the fatty acid composition and the oxidative stability of the oil from aqueous extraction were determined and compared to the oil extracted with hexane.

\section{MATERIALS AND METHODS}

\subsection{Samples}

The jerivá fruits were collected between January and May, 2017 in the south-east region of Brazil (Lavras, Minas Gerais state). All the fruits were collected directly from the ground, and they were ripe, firm and had no injuries. Whole fruits were dried at room temperature for 5 days. After drying, the kernel was separated from the core with the aid of a vice. The moisture was determined immediately before each extraction process 
using a moisture determination balance (i-Thermo $163 \mathrm{~L}$ - BEL Engineering) at $105^{\circ} \mathrm{C}$.

\subsection{Aqueous extraction}

About $30 \mathrm{~g}$ of jerivá kernels and $300.0 \mathrm{~mL}$ of distilled water were milled in a blender for $5 \mathrm{~min}$ utes. Then the $\mathrm{pH}$ was adjusted according to a factorial design (Table 1) using $\mathrm{NaOH} 1.0 \mathrm{~mol} \cdot \mathrm{L}^{-1}$ or $\mathrm{HCl} 1.0 \mathrm{~mol} \cdot \mathrm{L}^{-1}$. The mixture was agitated in a mechanical stirrer at $500 \mathrm{rpm}$ in a water bath at temperature and time according to the factorial design (Table 1). The mixture was centrifuged (relative centrifugal force of $2150 \mathrm{~g}$ ) for $10 \mathrm{~min}$ utes. In order to break up the emulsion, the upper phase was separated and cooled at $-10^{\circ} \mathrm{C}$ for $12 \mathrm{~h}$. The material was heated at $60{ }^{\circ} \mathrm{C}$ and centrifuged for 5 minutes. The oil was separated, weighed and stored in a closed bottle at $-10{ }^{\circ} \mathrm{C}$ until analysis. The yield was calculated by:

$$
\operatorname{Oil} \text { yeld }(\%)=\frac{\text { extracted oil }(g)}{\operatorname{kernel}(g) \times \frac{100-\text { moisture }(\%)}{100}} \times 100
$$

\subsection{Solvent extraction}

The extraction was carried out in a Soxhlet apparatus using hexane as extractor solvent. After solvent evaporation, the oil was weighed and stored in a closed bottle at $-10{ }^{\circ} \mathrm{C}$ until analysis.

\subsection{Oil characterization}

Each of the obtained oils was characterized according to the following parameters:

- Free acidity, expressed as the percentage of free oleic acid, according to the AOCS method $\mathrm{Ca}$ 5a-40 (2004).

- Peroxide value, expressed in milliequivalents active oxygen contained in $1 \mathrm{~kg}$ of oil, according to AOCS method Cd 8b-90.

- Iodine value, expressed as the amount of iodine absorbed by $100 \mathrm{~g}$ of sample, calculated using the fatty acid composition according to AOCS method Cd 1c-85.

- $\quad$ Saponification value, defined by the amount in milligrams of potassium hydroxide needed to saponify $1 \mathrm{~g}$ of oil or fat, calculated using the fatty acid composition by AOCS method Cd 3a-94.

TABLE 1. Yield, free acidity (FA) and peroxide value (PV) of the jerivá kernel oil from aqueous extraction according to a central composite factorial design. Values predicted by the fitted models are in parentheses

\begin{tabular}{|c|c|c|c|c|c|c|}
\hline Assay & pH (X1) & ${ }^{\circ} \mathrm{C}(\mathrm{X} 2)$ & minutes $(\mathrm{X} 3)$ & Yield (\%) & FA $(\%)$ & $\mathrm{PV}\left(\mathrm{meq} \mathrm{O}_{2} / \mathrm{kg}\right)$ \\
\hline 1 & $8(-1)$ & $34(-1)$ & $24(-1)$ & $33.3 \pm 0.3(33.1)$ & $4.1 \pm 0.2(3.3)$ & $5.5 \pm 0.5(3.3)$ \\
\hline 2 & $8(-1)$ & $34(-1)$ & $51(+1)$ & $36.7 \pm 0.6(34.4)$ & $4.3 \pm 0.5(3.3)$ & $5.7 \pm 0.4(2.3)$ \\
\hline 3 & $8(-1)$ & $61(+1)$ & $24(-1)$ & $30.6 \pm 0.4(30.7)$ & $3.1 \pm 0.2(3.3)$ & $5.9 \pm 0.4(3.7)$ \\
\hline 4 & $8(-1)$ & $61(+1)$ & $51(+1)$ & $29.4 \pm 0.5(29.5)$ & $2.8 \pm 0.1(3.3)$ & $8.9 \pm 0.5(4.7)$ \\
\hline 5 & $11(+1)$ & $34(-1)$ & $24(-1)$ & $35.9 \pm 0.6(34.6)$ & $0.2 \pm 0.1(0.3)$ & $9.8 \pm 0.3(7.9)$ \\
\hline 6 & $11(+1)$ & $34(-1)$ & $51(+1)$ & $36.3 \pm 0.5(35.8)$ & $0.2 \pm 0.1(0.3)$ & $9.7 \pm 0.4(6.8)$ \\
\hline 7 & $11(+1)$ & $61(+1)$ & $24(-1)$ & $31.5 \pm 0.4(32.2)$ & $0.3 \pm 0.1(0.3)$ & $11.7 \pm 0.2(8.2)$ \\
\hline 8 & $11(+1)$ & $61(+1)$ & $51(+1)$ & $31.5 \pm 0.7(31.0)$ & $0.4 \pm 0.2(0.3)$ & $13.0 \pm 0.4(9.3)$ \\
\hline 9 & $7(-1.68)$ & $47.5(0)$ & $37.5(0)$ & $28.2 \pm 0.7(28.9)$ & $4.6 \pm 0.3(4.4)$ & $6.8 \pm 0.5(3.4)$ \\
\hline 10 & $12(+1.68)$ & $47.5(0)$ & $37.5(0)$ & $31.1 \pm 0.4(31.4)$ & $0.1 \pm 0.1(-0.8)$ & $14.5 \pm 0.3(11.0)$ \\
\hline 11 & $9.5(0)$ & $25(-1.68)$ & $37.5(0)$ & $35.3 \pm 0.3(37.3)$ & $1.0 \pm 0.2(1.8)$ & $3.2 \pm 0.2(4.0)$ \\
\hline 12 & $9.5(0)$ & $70(+1.68)$ & $37.5(0)$ & $32.0 \pm 0.8(31.2)$ & $1.7 \pm 0.4(1.8)$ & $3.8 \pm 0.2(6.4)$ \\
\hline 13 & $9.5(0)$ & $47.5(0)$ & $15(-1.68)$ & $33.9 \pm 0.5(33.2)$ & $0.8 \pm 0.2(1.8)$ & $1.2 \pm 0.2(5.2)$ \\
\hline 14 & $9.5(0)$ & $47.5(0)$ & $60(+1.68)$ & $31.2 \pm 0.6(33.2)$ & $2.0 \pm 0.2(1.8)$ & $5.8 \pm 0.3(5.2)$ \\
\hline 15 & $9.5(0)$ & $47.5(0)$ & $37.5(0)$ & $30.6 \pm 0.7(30.1)$ & $1.3 \pm 0.1(1.8)$ & $7.8 \pm 0.5(7.2)$ \\
\hline 16 & $9.5(0)$ & $47.5(0)$ & $37.5(0)$ & $30.2 \pm 0.5(30.1)$ & $1.9 \pm 0.3(1.8)$ & $6.8 \pm 0.4(7.2)$ \\
\hline 17 & $9.5(0)$ & $47.5(0)$ & $37.5(0)$ & $29.8 \pm 0.4(30.1)$ & $1.9 \pm 0.2(1.8)$ & $7.6 \pm 0.3(7.2)$ \\
\hline
\end{tabular}

Mean \pm standard deviation $(\mathrm{n}=3)$. 
- Oxidative stability, expressed as the induction period in hours determined using $3 \mathrm{~g}$ of sample in Rancimat apparatus at $110^{\circ} \mathrm{C}$ with an airflow rate of $20 \mathrm{~L} \cdot \mathrm{h}^{-1}$ and $60 \mathrm{~mL}$ of distilled water in vials containing electrodes, according to AOCS method Cd 12b-92.

- Fatty acid composition. Samples were transesterified into methyl esters using potassium hydroxide in methanol and n-hexane, according to AOCS method Ce 2-66. The methyl esters were analyzed by gas chromatography (GC-2010 - Shimadzu) equipped with a flame ionization detector and an SPTM-2560 capillary column $(100 \mathrm{~mm} \times 0.25 \mathrm{~mm} \times 0.2 \mu \mathrm{m})$. The standard used was a mixture of 37 methyl esters (Supelco 37 Component FAME Mix). The following operational parameters were used: split injection mode, split ratio 1:100; $1 \mu \mathrm{L}$ injection volume; $260^{\circ} \mathrm{C}$ detector temperature; $260{ }^{\circ} \mathrm{C}$ injector temperature; oven temperature program: held at $60{ }^{\circ} \mathrm{C}$ for 1 minute, ramped at $4{ }^{\circ} \mathrm{C} \cdot \mathrm{min}^{-1}$ to $140{ }^{\circ} \mathrm{C}$, held for $5 \mathrm{~min}$ utes; ramped at $4{ }^{\circ} \mathrm{C} \cdot \mathrm{min}^{-1}$ to $240{ }^{\circ} \mathrm{C}$, held for 30 minutes. Peak identification was resolved by comparing the retention times of the fatty acid methyl ester standards with the retention times of the observed peaks. Quantification was done by normalization $(\%)$.

\subsection{Statistical analysis}

The effects of $\mathrm{pH}$ (from 7 to 12), temperature (from 25 to $70{ }^{\circ} \mathrm{C}$ ) and time (from 15 to $60 \mathrm{~min}$.) on the aqueous extraction process of JKO were evaluated by a five-level tree-variable central composite design (Table 1) and response surface methodology (RSM). The effects were evaluated on yield, free acidity, and peroxide value. The measurements were carried out in triplicate. The models for RSM were fitted using codified variables, and only significant $(\mathrm{p} \leq 0.05)$ regression coefficients were considered. Polynomial models of first-order (linear) or secondorder (quadratic) were evaluated by ANOVA in order to find the one that provided the best fit for the data. All calculations and graphs were carried out using Chemoface software (Nunes et al., 2012).

\section{RESULTS AND DISCUSSION}

\subsection{Effect of $\mathrm{pH}$, temperature and time on oil yield}

Initially, the effect of $\mathrm{pH}$, temperature, time, agitation speed, and solid/water ratio on oil yield was evaluated in a preliminary study. No relevant effect was detected for agitation speed or solid/ water ration. Hanmoungjai et al., (2000) also verified no substantial effect of agitation speed or solid/ water ratio on the aqueous extraction of rice bran oil, but $\mathrm{pH}$, time and temperature influenced the yield. As reported by those authors, it also verified that despite the solid/water ratio being irrelevant for yield, a high solid/water ratio resulted in a mixture which was too hard to be appropriately agitated. Therefore, the solid/water ratio was fixed at 1:10 and the agitation speed at $500 \mathrm{rpm}$. Extractions at $\mathrm{pH}$ below 7 resulted in low yield, and therefore the factorial design considered a $\mathrm{pH}$ range above 7 .

According to assays from the central composite factorial design, the yield varied from $28 \%$ to $37 \%$ (Table 1), which corresponds to recoveries from $57 \%$ to $76 \%$ compared to the yield of $49 \mathrm{~g} \cdot 100 \mathrm{~g}^{-1}$ obtained by extraction with hexane.

The $\mathrm{pH}$ values, temperature and time from the factorial design were regressed against the respective yield (Table 1) using least square regression. A quadratic model gave the best fit (Equation 2), with significant regression and non-significant lack of fit (Table 2). The linear coefficients for time, as well as the interactions between $\mathrm{pH}$ and temperature and $\mathrm{pH}$ and time were non-significant $(\mathrm{p}>0.05)$. The regression coefficients (Equation 2) indicated that temperature (X2) had the greatest influence on the yield, with a larger yield at lower temperatures. The $\mathrm{pH}$ (X1) had a small influence, and only its linear coefficient was significant, with a larger yield at

TABLE 2. ANOVA from surface response models for $\mathrm{pH}$, temperature and time over the yield, free acidity and peroxide value of the jerivá kernel oil from aqueous extraction

\begin{tabular}{|c|c|c|c|c|c|c|}
\hline & & SS & DF & MS & $\mathbf{F}$ & p \\
\hline \multirow[t]{6}{*}{ Yield } & Regression & 88.2 & 5 & 17.6 & 10.7 & 0.00 \\
\hline & Residual & 18.2 & 11 & 1.7 & & \\
\hline & Lack-of-fit & 14.2 & 8 & 1.8 & 1.3 & 0.45 \\
\hline & Pure error & 4.0 & 3 & 1.3 & & \\
\hline & Total & 106.4 & 16 & & & \\
\hline & $\mathrm{R}^{2}$ & 0.83 & & & & \\
\hline \multirow{6}{*}{$\begin{array}{l}\text { Free } \\
\text { acidity }\end{array}$} & Regression & 31.6 & 1.0 & 31.6 & 101.5 & 0.000 \\
\hline & Residual & 4.7 & 15.0 & 0.3 & & \\
\hline & Lack-of-fit & 1.6 & 3.0 & 0.5 & 2.1 & 0.15 \\
\hline & Pure error & 3.0 & 12.0 & 0.3 & & \\
\hline & Total & 36.2 & 16.0 & & & \\
\hline & $\mathrm{R}^{2}$ & 0.87 & & & & \\
\hline \multirow{6}{*}{$\begin{array}{l}\text { Peroxide } \\
\text { value }\end{array}$} & Regression & 157.4 & 6.0 & 26.2 & 7.0 & 0.00 \\
\hline & Residual & 37.2 & 10.0 & 3.7 & & \\
\hline & Lack-of-fit & 36.7 & 8.0 & 4.6 & 16.4 & 0.06 \\
\hline & Pure error & 0.6 & 2.0 & 0.3 & & \\
\hline & Total & 194.6 & 16.0 & & & \\
\hline & $\mathrm{R}^{2}$ & 0.81 & & & & \\
\hline
\end{tabular}


higher $\mathrm{pH}$, which can be verified by comparison of assays 1-4 with 5-6 and 9 with 10 (Table 1). Although the linear coefficient for time (X3) was not significant, its interaction with temperature (X2X3) was significant and negative. Therefore, if lower temperatures resulted in larger yield, this should be more effective at longer times. In fact, the larger yields were reached especially under this condition, such as in assays 2 and 6 (Table 1).

$$
\begin{aligned}
& \mathrm{Y}=30.13+0.74 \mathrm{X} 1-1,81 \mathrm{X} 2-0.63 \mathrm{X} 2 \mathrm{X} 3+ \\
& 1.46 \mathrm{X}^{2}+1.07 \mathrm{X}^{2}
\end{aligned}
$$

The response surface in Figure 1-A shows how the yield varied against temperature and time, thus confirming the interaction effect between these variables. It is clear that larger yields were reached especially by combinations of low temperature $\left(25-34{ }^{\circ} \mathrm{C}\right)$ and extended time (51-60 min.). This influence also was evidenced when the $\mathrm{pH}$ was considered, wherein for any $\mathrm{pH}$, the yield was large at mild temperatures $\left(25-34{ }^{\circ} \mathrm{C}\right)$ and at large periods of times (51-60 min.). Initially, the driving force for extraction is high because the concentration gradient of oil between the solid surface and the bulk of the solution is high, but after the initial period, the driving force is low, and the oil has to diffuse from the interior of the solid (Khoei and Chekin, 2016). However, this is overcome by the increase in the solubilization of cell wall components with the increase in extraction time. Despite the tendency of the oil viscosity to decrease with the increase in temperature and favor the withdrawal of oil from plant tissues, excessive temperatures can cause the coagulation of proteins and oil can be trapped in these structures (Ghorbanzadeh and Rezaei, 2017). Considering the coefficients of Equation 2, the temperature had a more relevant effect on the yield than time, and the negative effects of a high temperature can be compensated by a more extensive time of extraction, explaining the significant interaction between these variables.
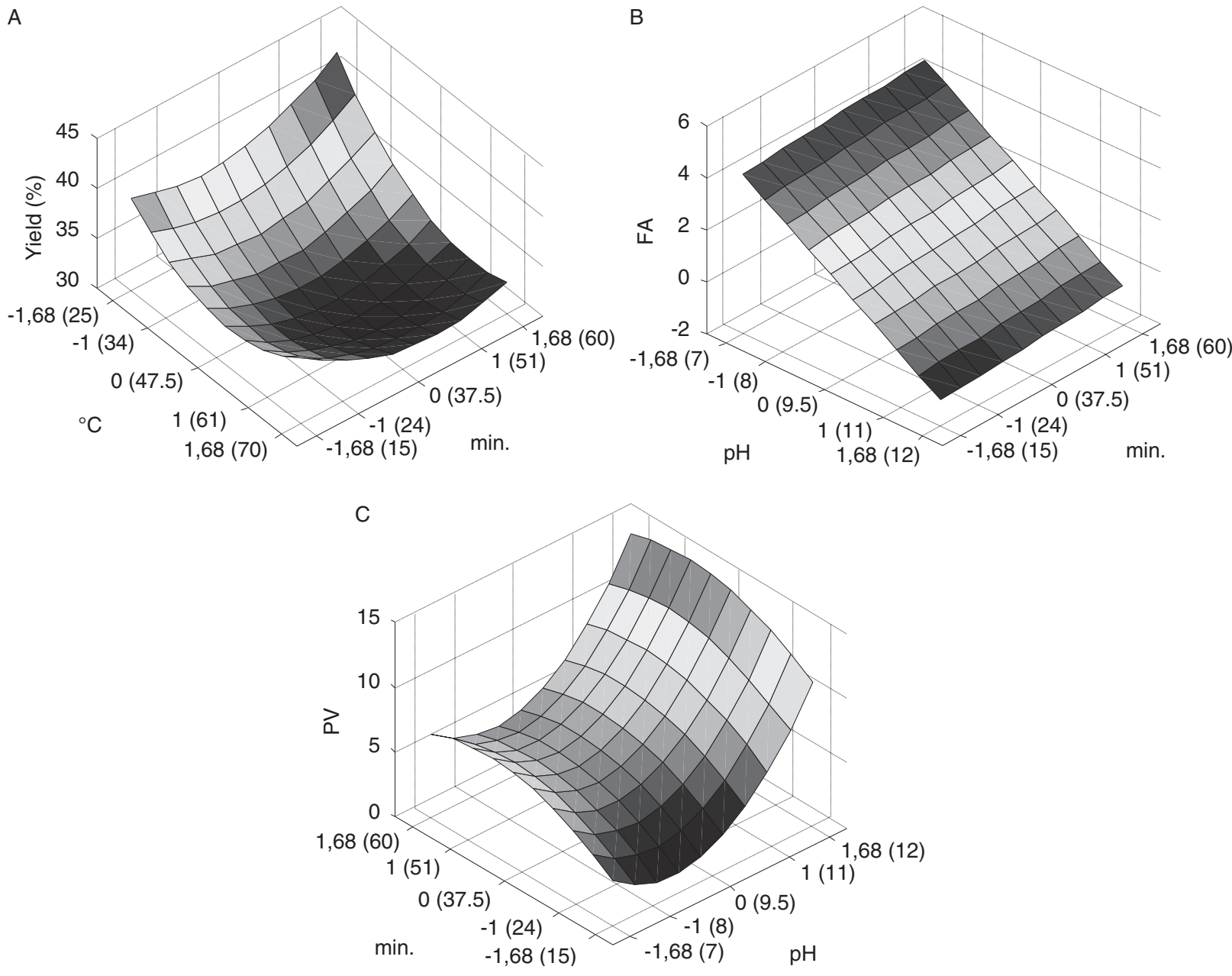

FigurE 1. Surface responses for $\mathrm{pH}$, temperature and time over the yield (A, $\mathrm{pH}$ fixed at 11), free acidity (B, temperature fixed at $\left.34{ }^{\circ} \mathrm{C}\right)$ and peroxide value $\left(\mathrm{C}\right.$, temperature fixed at $\left.34^{\circ} \mathrm{C}\right)$ of the jerivá kernel oil from aqueous extraction. 
Regardless of temperature and time, the increase in $\mathrm{pH}$ contributed to increasing the yield only slightly. This low effect of $\mathrm{pH}$ on the yield can be due to the fact that the tested range of $\mathrm{pH}$ (from 7 to 12 ) is in a maximum extractability range. Similar results also were observed in the aqueous extraction of soybean oil, where a modest increase in extractability was reached along the $\mathrm{pH}$ range of 8 to 12, with a steep drop below pH 7 (Rosenthal et al.; 1998). In fact, our preliminary tests revealed that the yields at $\mathrm{pH}$ below 7 were low (below 15\%), which induced the definition of the $\mathrm{pH}$ to be considered in the experimental design. It has been reported that the $\mathrm{pH}$ has an effect on the extractability in an aqueous extraction process. The protein solubility, which depends on the isoelectric point of the protein in the oil source, is influenced by $\mathrm{pH}$ and affects the extraction of oil from the particles. The stability and solubility of the oleosins which surround the oil droplets are also affected by changes in $\mathrm{pH}$, resulting in a difference in the release of oil droplets from the source. The $\mathrm{pH}$ also affects the oleosins in the membrane of fatty tissues, changing its stability and, consequently, the accumulation of fat globules. Therefore, the optimal $\mathrm{pH}$ for aqueous extraction of oils from different sources can vary due to the different proteins in their structures (Ghorbanzadeh and Rezaei, 2017; Nikiforidis and Kiosseoglou, 2009). Despite most aqueous extraction processes achieving their greatest yields at high $\mathrm{pH}$ due to the protein solubility being highest at basic pH (Campbell et al., 2011; Khoei and Chekin, 2016; Rosenthal et al., 1998), for some oil sources the best $\mathrm{pH}$ for extraction can be low (Ghorbanzadeh and Rezaei, 2017).

\subsection{Effect of pH, temperature and time over oil quality}

RSM was used to evaluate the effect of $\mathrm{pH}$, temperature and time on the free acidity and peroxide value of the JKO from the aqueous process.

The free acidity varied from 0.1 to $4.6 \%$ with the different experimental conditions of aqueous extraction, while the oil extracted with solvent had a free acidity of $1.4 \%$. Only the $\mathrm{pH}$ (X1) had a significant effect $(p<0.05)$ on free acidity, which was fitted with a linear model (Equation 3 ) with significant regression and no lack of fit (Table 2):

$$
\mathrm{Y}=1,81-1,52 \mathrm{X} 1
$$

The response surface in Figure 1-B shows how $\mathrm{pH}$ and time (considering its non-significant linear coefficient) influenced free acidity, which confirms the irrelevance of the time over free acidity compared to the substantial effect of $\mathrm{pH}$. A similar graph (not presented) also confirmed the irrelevance of the temperature over free acidity when compared to the influence of $\mathrm{pH}$. The increase in $\mathrm{pH}$ resulted in a proportional decrease in free acidity, which was probably a consequence of the neutralization of free fatty acids on the alkaline medium of extraction. This effect was also observed in other aqueous extraction processes at high $\mathrm{pH}$, such as for rice bran oil, with a free acidity of less than $0.5 \%$ in oils obtained from extractions at $\mathrm{pH} 12$ (Khoei and Chekin, 2016; Hanmoungjai et al., 2000).

The peroxide value of the oils from aqueous extraction varied from 1.2 to $14.5 \mathrm{meqO}_{2} / \mathrm{kg}$, while the oil extracted with solvent had $9.3 \mathrm{meqO}_{2} / \mathrm{kg}$. The peroxide value was significantly influenced by $\mathrm{pH}$, temperature and time, which was fitted with a quadratic model (Equation 4) with significant regression and no lack of fit (Table 2):

$$
\begin{aligned}
& \mathrm{Y}=7.21+2.28 \mathrm{X} 1+0.72 \mathrm{X} 2+0.89 \mathrm{X} 3+ \\
& 1.81 \mathrm{X}^{2}-0.72 \mathrm{X}^{2}-0.72 \mathrm{X} 3^{2}
\end{aligned}
$$

$\mathrm{pH}$ had the most substantial effect on the peroxide value when compared to the effects of time and temperature. The response surface in Figure 1-C shows how the peroxide value varied with $\mathrm{pH}$ and extraction time, which evidences a considerable increase in peroxide value with the increase in $\mathrm{pH}$. This high effect of the $\mathrm{pH}$ also was observed when $\mathrm{pH}$ and temperature were plotted against the peroxide value (not presented). It is known that the lipoxygenase activity can be increased with an increase in $\mathrm{pH}$, such as for soybean, where the lipoxygenase activity increases in the $\mathrm{pH}$ range from 7 to 9 (Ali Asbi et al., 1989). However, this enzyme is quickly inactivated at temperatures between 50 and $70{ }^{\circ} \mathrm{C}$ (Ludikhuyze et al., 1998), a range in which high peroxide values were observed in the aqueous extraction of JKO, especially at the most prolonged periods of time. So, a plausible explanation for the observed effects is that the presence of hydroxide ions $\left(\mathrm{OH}^{-}\right)$can accelerate the hydrolysis of triacylglycerols into diacylglycerols, monoacylglycerols, and free fatty acids through saponification, which corroborates the more substantial effect of $\mathrm{pH}$ (larger coefficient in Equation 4) in comparison to time and temperature. These species are amphiphilic compounds and can accelerate the rate of lipid oxidation through the formation of association colloids, once the interface between water and oil is a possible location for lipid oxidation (Chaiyasit et al., 2007; Kim et al., 2016).

\subsection{Numerical optimization}

A numerical optimization combining all ranges of $\mathrm{pH}$, temperature and time was carried out using the fitted models (Equations 2-4). The optimal condition to maximize yield was found to be $\mathrm{pH} 12,25^{\circ} \mathrm{C}$ and 60 minutes. On the other hand, numerical optimizations aiming to improve the oil 
quality indicated that extraction at $\mathrm{pH} 12,25^{\circ} \mathrm{C}$ and 15 minutes minimizes the free acidity, while an extraction at $\mathrm{pH} 8.6,25^{\circ} \mathrm{C}$ and 15 minutes minimizes the peroxide value. However, the predicted yield on these conditions was low. Then, the optimal extraction at $\mathrm{pH} 12,25^{\circ} \mathrm{C}$ and 60 minutes was carried out, which resulted in a higher yield of $39 \%$, thus validating the optimized condition. This oil had a free acidity of $0.2 \%$, a peroxide value of $5.8 \mathrm{meqO}_{2} / \mathrm{kg}$, and was analyzed for fatty acid content and oxidative stability.

\subsection{Fatty acid composition and oxidative stability}

In general, the oils from aqueous extraction and solvent extraction had a predominance of lauric acid (C12:0) and oleic acid (C18:1) (Table 3). Coimbra and Jorge (2011), Pierezana et al., (2015) and Moreira et al., (2013) also reported JKOs with higher contents of lauric and oleic acid, but other authors also reported the predominance of palmitic (C16:0) and linoleic (C18:2) in addition to oleic (Kobelnik et al.; 2011). These variations can be due to effects of region of growth, climate, fruit maturation level, harvest season and extraction method.

The oil from aqueous extraction had a higher proportion of unsaturated fatty acids when compared to the oils extracted with hexane (Table 3). The same was observed for the aqueous extraction of pomegranate seed oil (Ghorbanzadeh and Rezaei, 2017) and Clanis bilineata oil (Sun et al., 2018). A higher proportion of short-chain saturated fatty acids (C6:0) and a proportion modestly lower of medium-chain saturated fatty acids

TABLE 3. Fatty acid composition and oxidative stability of the jerivá kernel oil from aqueous extraction

\begin{tabular}{lcc}
\hline Fatty acid & $\begin{array}{c}\text { Hexane } \\
\text { extraction }\end{array}$ & $\begin{array}{c}\text { Aqueous } \\
\text { extraction }\end{array}$ \\
\hline $\mathrm{C} 6: 0$ & $0.8 \pm 0.1$ & $2.6 \pm 0.2$ \\
$\mathrm{C} 8: 0$ & $13.1 \pm 0.3$ & $8.4 \pm 0.2$ \\
$\mathrm{C} 10: 0$ & $11.1 \pm 0.3$ & $8.2 \pm 0.1$ \\
$\mathrm{C} 12: 0$ & $44.0 \pm 0.5$ & $33.8 \pm 0.4$ \\
$\mathrm{C} 14: 0$ & $8.4 \pm 0.2$ & $8.6 \pm 0.3$ \\
$\mathrm{C} 16: 0$ & $4.9 \pm 0.1$ & $9.9 \pm 0.3$ \\
$\mathrm{C} 18: 0$ & $1.8 \pm 0.1$ & $2.3 \pm 0.1$ \\
$\mathrm{C} 18: 1 \mathrm{n} 9 \mathrm{c}$ & $13.2 \pm 0.1$ & $20.3 \pm 0.3$ \\
$\mathrm{C} 18: 2 \mathrm{n} 6 \mathrm{c}$ & $2.6 \pm 0.2$ & $6.0 \pm 0.1$ \\
Esaturated & $84.2^{*}$ & $73.7^{*}$ \\
Eunsaturated & $15.8^{*}$ & $26.3^{*}$ \\
Iodine value $\left(\mathrm{gI}_{2} \cdot 100 \mathrm{~g}^{-1}\right)$ & $15.9^{*}$ & $27.8^{*}$ \\
Saponification value $\left(\mathrm{mgKOH} \cdot \mathrm{g}^{-1}\right)$ & $253.3^{*}$ & $238.5^{*}$ \\
Oxidative stability $(\mathrm{h})$ & $23.2 \pm 1.0$ & $12.3 \pm 0.8$ \\
\hline
\end{tabular}

Mean \pm standard deviation $(\mathrm{n}=2)$. ${ }^{*}$ Calculated by the fatty acid averages.
(C8:0 and C10:0) were also verified. The proportion of lauric $(\mathrm{C} 12: 0)$ acid in the oil from aqueous extraction was lower than that found in the oil extracted with hexane. On the other hand, the proportions of long-chain saturated fatty acids (C16:0 and C18:0) were higher, as also occurred for oleic and linoleic. A plausible explanation for these differences can be based on the different affinity of fatty acids for the aqueous medium, which is influenced by the chain length and unsaturation level. It was demonstrated that, although low, the solubility of saturated fatty acids in water increases with the decrease in chain length (Khuwijitjaru et al., 2002) and that monounsaturated (C18:1) and polyunsaturated (C18:2) fatty acids are more soluble in hot water than the saturated fatty acid with equal chain length (C18:0) (Khuwijitjaru et al., 2004). Triacylglycerols with short-chain saturated fatty acids or unsaturated fatty acids would therefore benefit the migration from vegetable tissue to the aqueous medium, which explains the higher proportions of caproic (C6:0), oleic $(\mathrm{C} 18: 1)$ e linoleic (C18:2) acids in the oil from aqueous extraction.

The iodine and saponification values were calculated from the fatty acid profile (Table 3 ). The iodine value was higher in the oil from aqueous extraction, which was expected because of its higher proportion of unsaturated fatty acids. The oil from aqueous extraction had a slightly lower saponification value, indicating that this oil had a higher average molecular weight of fatty acid when compared to the oil extracted with hexane.

The oil from aqueous extraction showed less oxidative stability $(12.3 \mathrm{~h})$ than the oil extracted with solvent $(23.2 \mathrm{~h})$. Higher antioxidant activity was reported for oils from aqueous extraction when compared with oils from solvent extraction, which could be due to a higher content of tocopherols in oils from aqueous extraction (Ghorbanzadeh and Rezaei, 2017; Jiao et al., 2014). However, no consistent correlation $\left(\mathrm{R}^{2}=0.26\right)$ was found between tocopherol content and oxidative stability index in a study of the aqueous extraction of pumpkin seed oil (Li et al., 2016). The lower oxidative stability of the oil from aqueous extraction in the present study can be a consequence of the higher proportion of unsaturated fatty acids in the oil from aqueous extraction. Other authors reported oxidative stability of $44.5 \mathrm{~h}$ for JKO extracted with petroleum ether (Coimbra and Jorge, 2011) and $21.6 \mathrm{~h}$ for oil extracted with hexane (Moreira et al., 2013), which proves the effect of solvent on the oxidative stability of oils.

\section{CONCLUSIONS}

High $\mathrm{pH}$ and time, and mild temperature are suitable conditions to extract jerivá kernel oil by aqueous extraction, but excessively high $\mathrm{pH}$, temperature and time can negatively impact the 
oil quality, specially the peroxide value. $\mathrm{pH}$ was the only variable that significantly influenced the free acidity, with a decrease in free acidity with the increase in $\mathrm{pH}$. On the other hand, the increase in $\mathrm{pH}$, time and temperature increased the peroxide value, which limited some conditions to obtain jerivá kernel oil by aqueous extraction. The optimized condition was found to be an extraction at $\mathrm{pH} 12,25^{\circ} \mathrm{C}$ and 60 minutes, which resulted in high yield and low free acidity and peroxide value. The aqueous extraction yielded a more unsaturated oil than the one extracted with hexane, in addition to higher proportions of caproic (C6:0), oleic (C18:1) and linoleic (C18:2) acids, thus improving its nutritional characteristics and health benefits, despite decreasing its oxidative stability.

\section{ACKNOWLEDGMENTS}

This study was supported by Conselho Nacional de Desenvolvimento Científico e Tecnológico (CNPq, Brazil) and Fundação de Amparo à Pesquisa de Minas Gerais (FAPEMIG, Brazil, APQ-00638-14 and PPM-00498-16). The authors would like to thank the Central of Analysis and Chemical Prospecting of the Federal University of Lavras, Finep and Capes for supplying the equipment and technical support for experiments involving chromatographic analyses.

\section{REFERENCES}

Ali Asbi B, Wei LS, Steinberg MP. 1989. Effect of $\mathrm{pH}$ on the Kinetics of Soybean Lipoxygenase-1. J Food Sci. 54, 1594-1600. https://doi.org/10.1111/j.1365-2621.1989. tb05167.x

American Oil Chemists Society. Official methods and recommended praticces of the American Oil Chemists' Society. 4th ed. Champaign, USA, AOCS.

Barbosa MZB, Nogueira Júnior S, Freitas SM. 2008. Agricultura de alimentos X de energia: impacto nas cotações internacionais. Análises e Indicadores do Agronegócio 3, 1-5.

Campbell KA, Glatz CE, Johnson LA, Jung S, Moura JMN, Kapchie V, Murphu P. 2011. Advances in Aqueous Extraction Processing of Soybeans. J. Am. Oil Chem. Soc. 88, 449-465. https://doi.org/10.1007/s11746-010-1724-5

Chaiyasit W, Elias RJ, Mcclements DJ, Decker EA. 2007. Role of physical structures in bulk oils on lipid oxidation. Crit. Rev. Food. Sci. Nutrit. 47, 299-317. https://doi.org/ 10.1080/10408390600754248

Coimbra MC, Jorge N. 2011. Characterization of the Pulp and Kernel Oils from Syagrus oleracea, Syagrus romanzoffiana, and Acrocomia aculeata. J. Food Sci. 76, C1156-61. https:// doi.org/10.1111/j.1750-3841.2011.02358.x

Coimbra MC, Jorge N. 2012. Fatty acids and bioactive compounds of the pulps and kernels of Brazilian palm species, guariroba (Syagrus oleraces), jerivá (Syagrus romanzoffiana) and macaúba (Acrocomia aculeata). J. Sci. Food Agric. 92, 679-684. https://doi.org/10.1002/jsfa.4630

Falasca SL, Miranda del Fresno C, Ulberich A. 2012. Possibilities for growing queen palm (Syagrus romanzoffiana) in Argentina as a biodiesel producer under semi-arid climate conditions. Int. J. Hydrog. Energy 37, 14843-14848. https://doi.org/10.1016/j.ijhydene.2011.12.092
Garcés R, Martínez-Force E, Venegas-Calerón M, Salas JJ. 2017. Oils and fats on food: is it possible to have a healthy diet? Grasas Aceites $\mathbf{6 8}$, e200.

Ghorbanzadeh R, Rezaei K. 2017. Optimization of an Aqueous Extraction Process for Pomegranate Seed Oil. J. Am. Oil. Chem. Soc. 94, 1491-1501. https://doi.org/10.1007/ s11746-017-3045-4

Hanmoungjai P, Pyle L, Niranjan K. 2000. Extraction of rice bran oil using aqueous media. J Chem. Technol. Biotechnol. 75, 348-35. https://doi.org/10.1002/(SICI)10974660(200005)75:5<348::AID-JCTB233>3.0.CO;2-P

Jiao J, Li ZG, Gai QY, Li XJ, Wei FY, Fu YJ, Ma W. 2014 Microwave-assisted aqueous enzymatic extraction of oil from pumpkin seeds and evaluation of its physicochemical properties, fatty acid compositions and antioxidant activities. Food Chem. 147, 17-24. https://doi.org/10.1016/j. foodchem.2013.09.079

Khoei M, Chekin F. 2016. The ultrasound-assisted aqueous extraction of rice bran oil. Food Chem. 194, 503-507. https://doi.org/10.1016/j.foodchem.2015.08.068

Khuwijitjaru P, Adachi S, Matsuno R. 2002. Solubility of saturated fatty acids in water at elevated temperatures. Biosci. Biotechnol. Biochem. 66, 1723-6. https://doi.org/10.1271/ bbb. 66.1723

Khuwijitjaru P, Kimura Y, Matsuno R, Adachi S. 2004. Solubility of Oleic and Linoleic Acids in Subcritical Water. Food. Sci. Technol. Res. 10, 261-263. https://doi. org/10.3136/fstr.10.261

Kim JY, Bora Y, Chankyu L, Seo-Yeong G, Mi-Ja K, Jaehwan L. 2016. Effects of $\mathrm{pH}$ on the rates of lipid oxidation in oil-water system. Appl. Biol. Chem. 59, 157-161. https:// doi.org/10.1007/s13765-015-0146-3

Kobelnik M, Cassimiro DL, Dias DS, Ribeiro CA, Crespi MS. 2011. Thermal behavior of jerivá oil (Syagrus romanzoffiana). J. Therm. Anal. Calorim. 106, 711-715. https://doi. org/10.1007/s10973-011-1308-0

Lescano CH, Oliveira IP, Lima FF, Baldivia DS, Justi PN, Cardoso CAL, Raposo Júnior JL, Sanjinez-Argandoña EJ. 2018. Nutritional and chemical characterizations of fruits obtained from Syagrus romanzoffiana, Attalea dubia, Attalea phalerata and Mauritia flexuosa. J. Food Meas. Charact. 12, 1284-1294. https://doi.org/10.1007/s11694-018-9742-3

Li P, Gasmalla MAA, Zhang W, Liu J, Bing R, Yang R. 2016. Effects of roasting temperatures and grinding type on the yields of oil and protein obtained by aqueous extraction processing. J. Food Eng. 173, 15-24. https://doi. org/10.1016/j.jfoodeng.2015.10.031

Ludikhuyze L, Indrawati I, Van Den Broeck C, Weemaes C, Hendrickx M. 1998. Effect of Combined Pressure and Temperature on Soybean Lipoxygenase. 1. Influence of Extrinsic and Intrinsic Factors on Isobaric-Isothermal Inactivation Kinetics. J. Agric. Food Chem. 46, 4074-4080. https://doi.org/10.1021/jf980256c

Mat Yusoff M, Gordon MH, Ezeh O, Niranjan K. 2016. Aqueous enzymatic extraction of Moringa oleifera oil. Food Chem. 211, 400-408. https://doi.org/10.1016/j.foodchem.2016.05.050

Moreira MAC, Payret Arrúa ME, Antunes AC, Fiuza TER, Costa BJ, Weirich Neto PH, Antunes SRM. 2013. Characterization of Syagrus romanzoffiana oil aiming at biodiesel production. Ind. Crops. Prod. 48, 57-60. https:// doi.org/10.1016/j.indcrop.2013.04.006

Nikiforidis CV, Kiosseoglou V. 2009. Aqueous Extraction of Oil Bodies from Maize Germ (Zea mays) and Characterization of the Resulting Natural Oil-in-Water Emulsion. J. Agric. Food Chem. 57, 5591-5596. https://doi. org/10.1021/jf900771v

Nunes CA, Freitas MP, Pinheiro ACM, Bastos SC. 2012. Chemoface: a novel free user-friendly interface for chemometrics. J. Brazil. Chem. Soc. 23, 2003-2010. https://doi. org/10.1590/S0103-50532012005000073

Pierezana L, Cabral MRP, Neto DM, Stropa JM, Oliveira LCS, Scharf DR, Simionatto EL, Silva RCL, Simionatto E. 
Effect of process variables on the yield and quality of jerivá (Syagrus romanzoffiana) kernel oil from aqueous extraction $\bullet 9$

2015. Chemical composition and crystallization temperatures of esters obtained from four vegetable oils extracted from seeds of Brazilian Cerrado plants. Ouím. Nova 38, 328-332. https://doi.org/10.5935/0100-4042.20150018 Rosenthal A, Pyle DL, Niranjan K. 1998. Simultaneous Aqueous Extraction of Oil and Protein from Soybean: Mechanisms for Process Design. Food Bioprod. Process. 76, 224-230. https://doi.org/10.1205/096030898532124

Sun M, Xu X, Zhang Q, Xinrui, Wu J, Dong M. 2018. Ultrasonicassisted Aqueous Extraction and Physicochemical Characterization of Oil from Clanis bilineata. J. Oil. Sci. 67, 151-165. https://doi.org/10.5650/jos.ess17108 